\title{
The relationship of ordinal position and sibling sex status to cognitive abilities'
}

\author{
B. G. Rosenberg and B. Sutton-Smith \\ BOWLING GREEN STATE UNIVERSITY
}

\begin{abstract}
The influence of the interaction of ordinal position and sibling sex status on cognitive activity was examined. Results generally confirm the superiority of the first born over the second born on cognitive activity. Directional trends suggest that the presence of a male sibling enhances quantitative scores, the presence of a female enhances language scores, males having a greater effect on females than vice versa.
\end{abstract}

\section{Problem}

The literature regarding the effects of ordinal position on intellectual activities is inconsistent, with some studies emphasizing the superiority of the first born (Altus, 1962; Koch, 1954; Terman, 1947) and some the superiority of the second born (Hsiao, 1931; Mc Fadden, 1929; Thurstone \& Jenkins, 1929). Except for Koch's study with six-year-olds, there has been no control for age, socio-economic status, or family size. The present study replicates Koch's work with the eight different sibling combinations in two-child families in order to examine the effects of ordinal position, sex of subject, and sex of sibling (sibling sex status) on cognitive activity using adult Ss with controls for age and socioeconomic status.

\section{Method}

Data on the ACE (Berdie et al., 1961) was obtained for 125 male and 252 female members of two-child families (college sophomores, predominantly). The sample contained $32 \mathrm{M} 1 \mathrm{M}, 25 \mathrm{MM} 2,37 \mathrm{M} 1 \mathrm{~F}, 31 \mathrm{FM} 2$, and $70 \mathrm{~F} 1 \mathrm{~F}$, $61 \mathrm{FF} 2,68 \mathrm{~F} 1 \mathrm{M}$, and $53 \mathrm{MF} 2$. The notation states the sex and position referent with the number following the $\mathrm{S}$ and indicating his ordinal position. Thus, MM2 is a second-born male with an older brother, F1F is a firstborn female with a younger sister, etc. These groups did not differ in age by sex or ordinal position (median for all groups was $19 \mathrm{yr}$.), and $95 \%$ of all ordinal groups were in the 18-20-yr. age range. There was no significant difference between the groups when compared on a manual, non-manual socio-economic break. The ACE was routinely administered to all Ss as part of a test battery taken by all entering freshmen. These scores were obtained from the University Counseling Center.

\section{Results}

Since all of the data were presented in percentile form, the Median Test (Siegel, 1956) was used throughout the analysis. In addition, as a reflection of the malequantitative, female-linguistic adherence, $\mathrm{Q}>\mathrm{L}$ and $\mathrm{L}>\mathrm{Q}$ ratios are included. Table 1 presents the results for the entire sample by ordinal category. Generally, males are superior on the $Q$ (quantitative) scale
$\left(X^{2}=2.58 ; P=.12\right)$, while females are superior on the $L$ (linguistic) scale $\left(X^{2}=7.70 ; P=.01\right)$. No significant differences were obtained on the $\mathrm{T}$ (total) score. The $\mathrm{Q}>\mathrm{L}$ ratios favor males, while the $\mathrm{L}>\mathrm{Q}$ ratios favor females $\left(X^{2}=9.24 ; P=.01\right)$. When comparing first borns with second borns separately by sex, male first borns are superior to male second borns on the $\mathrm{L}$ $(\mathrm{P}=.05)$ and $\mathrm{T}(\mathrm{P}=.02)$ scales. No significant differences obtained among the females, first born females showing a slight superiority on the $L$ scale $(P=.12)$. First born males show a slight predominance on the $\mathrm{L}>\mathrm{Q}$ ratios $(\mathrm{P}=.20)$, while second born females show a predominance on the $\mathrm{Q}>\mathrm{L}$ ratios $(\mathrm{P}=.02)$. The effects of like vs. opposite sex sibling on ACE scores indicates, for males, that the presence of a sister tends to heighten $\mathrm{L}$ scores and $\mathrm{L}>\mathrm{Q}$ ratios, but the differences do not obtain significance. Similar findings were not obtained for girls.

\section{Diseussion}

The present analysis generally confirms the superiority of first borns over second borns on the ACE. As most of the more recent and more adequately controlled studies have found first borns to be superior (Altus,1962;

Table 1. ACE Median Scores and $\mathrm{Q}>\mathrm{L}$ Ratios for Individual Ordinal Groupings.

Males

\begin{tabular}{|c|c|c|c|c|}
\hline $\mathrm{ACE}$ & $\begin{array}{c}\text { M1M } \\
(\mathrm{N}=32)\end{array}$ & $\begin{array}{c}\text { M1F } \\
(\mathrm{N}=37)\end{array}$ & $\begin{array}{c}\text { MM2 } \\
(\mathrm{N}=25)\end{array}$ & $\begin{array}{c}\text { FM2 } \\
(\mathrm{N}=31)\end{array}$ \\
\hline Q & 78 & 67 & 60 & 67 \\
\hline $\mathrm{L}$ & 50 & 58 & 35 & 38 \\
\hline $\mathbf{T}$ & 58 & 58 & 42 & 50 \\
\hline $\mathrm{Q}>\mathrm{L}$ & 24 & 20 & 19 & 23 \\
\hline$L>Q$ & 8 & 17 & 6 & 8 \\
\hline \multicolumn{5}{|c|}{ Females } \\
\hline $\mathrm{ACE}$ & $\begin{array}{c}\mathrm{F} 1 \mathrm{~F} \\
(\mathrm{~N}=70)\end{array}$ & $\begin{array}{c}\text { F1M } \\
(\mathrm{N}=68)\end{array}$ & $\begin{array}{c}\text { FF2 } \\
(\mathrm{N}=61)\end{array}$ & $\begin{array}{c}\text { MF2 } \\
(\mathrm{N}=53)\end{array}$ \\
\hline Q & 56 & 56 & 64 & 60 \\
\hline $\mathrm{L}$ & 62 & 62 & 54 & 54 \\
\hline $\mathrm{T}$ & 61 & 55 & 58 & 58 \\
\hline $\mathrm{Q}>\mathrm{L}$ & 33 & 30 & 40 & 21 \\
\hline$L>Q$ & 37 & 38 & 21 & 24 \\
\hline
\end{tabular}


Koch, 1954), some degree of assurance may be felt in this finding.

In previous inquiries which employed a variety of selfreport measures of masculinity, femininity, and anxiety (Sutton-Smith et al., 1964; Rosenberg \& Sutton-Smith, in press; Sutton-Smith \& Rosenberg, in press), it was shown that ordinal position and sibling sex status had systematic effects upon the responses Ss made to these instruments. In the present study, a less noticeable effect was obtained. Though the presence of a brother tends to enhance $\mathrm{Q}$ scores and a sister to enhance $\mathrm{L}$ scores, the present evidence is not clear-cut. In general, males have a greater effect on females, than vice versa.

One last finding of note is the tendency for second borns, boys and girls, to have higher $Q>L$ ratios than first borns. The finding may be explicable on the grounds of greater removal or distance (i. e., more limited interaction) of second borns from the mother than first borns producing in them a problem-solving set (Lynn, 1962).

\section{References}

ALTUS, W. Sibling order and scholastic aptitude. Amer. Psychol., 1962, 17, 304. (Abstract)

BERDIE, R., DRESSEL, P., \& KELSO, P. Relative validity of the $Q$ and L scores of the ACE Psychological Examination. Educ.psychol. Measmt., 1951, 11, 803-812.

HSIAO, H. H. The status of the first born with specific reference to intelligence. Genetic Psychol. Monogr., $1931,9,1-118$.
KOCH, HELEN. The relation of "Primary Mental Abilities" in five- and six-year olds to sex of child and characteristics of his sibling. Child Developm., 1954, 25, 209-223.

LYNN, D. B. Sex-role and parental identification. Child Developm., 1962, 33, 555-564.

MCFADDEN, J. H. A further note on the differential I. Q.'s of siblings. J. appl. Psychol., 1929, 13, 86-91.

ROSENBERG, B. G., \& SUTTON-SMITH, B. Ordinal position and sex role identification.Genetic Psychol. Monogr., in press.

SIEGEL, S. Nonparametric statistics. New York: McGraw-Hill, 1956.

SUTTON-SMITH, B., ROBERTS, J. M. , \& ROSENBERG, B. G. Sibling associations and role involvement. Merrill-Palmer Quart., 1964, 10, 25-38.

SUTTON-SMITH, B., \& ROSENBERG, B. G. Age changes in the effects of ordinal position on sex role identification. J. genet. Psychol., in press.

TERMAN, L. M., and others. Genetic studies of genius. Vol. I. The mental and physical traits of a thousand gifted children. Stanford: Stanford Univer. Press, 1947.

THURSTONE, L. L., \& JENKINS, R. L. Birth order and intelligence. J.educ. Psychol., 1929, 20, 641-651.

\section{Note}

1. This work was supported by Grant MH 07354-01 from the National Institute of Mental Health. 